\title{
NOTAS ETNOGRÁFICAS SOBRE DUAS MANIFESTAÇÕES DE RUA DO ATIVISMO TRANS NO BRASIL
}

\section{Mario Felipe de Lima Carvalho}

Núcleo de Estudos de Políticas Públicas em Direitos Humanos da Universidade Federal do Rio de Janeiro (NEPP-DH/UFRJ), Rio de Janeiro - RJ, Brasil. E-mail: mariofelipec@gmail.com.

DOI: http//dx.doi.org/10.17666/339616/2018

\section{Introdução}

Uma das ferramentas mais tradicionais de visibilidade de diferentes lutas políticas é tomar as ruas. Entretanto, desde minha entrada no campo ${ }^{1}$ do ativismo trans ${ }^{2}$, estranhava o pouco uso deste tipo de repertório. A princípio, acredito que essa ausência se devia a alguns fatores: 1) o movimento ser pequeno; 2) a existência, talvez, de um receio quanto à receptividade da população em geral que poderia rechaçar as/os manifestantes; 3) a consolidação do modelo de paradas do orgulho como principal manifestação de rua do ativismo LGBT diminuiria a necessidade ou a vontade de se realizar outros tipos de manifestação; 4) a distância da práxis da esquerda mais tradicional, que tem nos atos de rua uma das suas principais ferramentas. Essas são apenas algu-

Artigo recebido em 27/11/2016

Aprovado em 01/06/2017 mas hipóteses que não puderam se confirmar nem negar com base em minhas investigaçóes.

Nesse sentido, não havia no início da minha pesquisa ${ }^{3}$ intenção de abordar protestos e outras manifestaçôes de rua. Porém, no início de 2014, tomei conhecimento de uma movimentação na internet para que o tema da $18^{a}$ Parada do Orgulho LGBT de São Paulo pautasse a aprovação do Projeto de Lei n. 5002/2013, também conhecido como PL João Nery, ${ }^{4}$ de autoria do deputado federal Jean Wyllys (Psol-RJ) e que visa à facilitação no processo de mudança de nome e sexo no registro civil. Menos de um ano depois, em janeiro de 2015, aconteceu o Ato pelo Dia Nacional da Visibilidade Trans do Rio de Janeiro, que contou com uma participação significativamente maior que o ato realizado dois anos antes, em janeiro de $2013 .{ }^{5}$ Esses fatos colocaram a rua como um palco para a ação política do ativismo trans brasileiro, que até então privilegiava a ação sobre a própria população trans 
(principalmente através de projetos de prevenção ao HIV/Aids junto a travestis prostitutas) e sobre agentes governamentais (em açóes de advocacy em canais de interação socioestatal). O fortalecimento dessa ferramenta política no repertório ativista não apenas coloca em relação os usos da internet, as produçóes de alianças políticas, a luta por visibilidade social e as novas e velhas dramaturgias políticas acionadas por ativistas trans, como também denota transformações nos sentidos e nas simbologias atribuídas à "rua".

Entre as manifestaçóes de rua etnografadas ao longo de meu trabalho de campo, ${ }^{6}$ optei por comparar as duas manifestaçóes citadas por se tratarem de experiências antagônicas no que tange ao seu "sucesso político" do ponto de vista nativo (sendo a primeira considerada uma derrota frente ao sucesso da segunda), ao mesmo tempo que acionam dramaturgias e repertórios semelhantes, a saber: 1) uso das redes sociais da internet; 2) estabelecimento de alianças com diferentes agrupamentos e instituições políticas; 3) uso do "corpo-bandeira". ${ }^{7}$ Por fim, busco elementos nos possíveis legados das chamadas "Jornadas de Junho" de 2013, no Brasil, tanto nas disputas representadas quanto nas diferentes avaliaçôes nativas com relação aos (in)sucessos das manifestaçôes, o que ganha colorido especial no cenário carioca.

Tomo a metáfora dramatúrgica de Erving Goffman (2009) como ferramenta analítica do material etnográfico. Nesse sentido, pessoas reunidas tendo a rua como palco representam papéis para uma plateia. Essas representaçóes não apenas transmitem várias informaçóes sobre ideais e reivindicações dos/ das que ali se manifestam, mas também tecem estratégias de diálogo com a plateia, que podem incluir tanto a provocação como a compaixão. Para Ilse Scherer-Warren (2014), as manifestaçóes seriam situaçóes pontuais, momentos públicos de visibilidade, de reivindicação, de demonstração de revolta ou protesto. Momentos que, ao serem percebidos como espetáculos, não perdem seu caráter político, mas ganham contornos analíticos especialmente interessantes para uma compreensão dos jogos de sentidos dos regimes de visibilidade em disputa, tanto internamente ao ativismo quanto em relação à sociedade englobante, ou o "respeitável público".

\section{$18^{a}$ Parada do Orgulho LGBT de Sáo Paulo}

$\mathrm{Na}$ tarde de 19 de janeiro de 2014, a Associação da Parada do Orgulho GLBT ${ }^{8}$ de São Paulo (APOGLBT) divulgou o tema da parada daquele ano: "País vencedor é país sem homofobia: Chega de mortes! Criminalização já”, numa alusão à Copa do Mundo de Futebol que aconteceria naquele ano e à reivindicação de uma legislação que tornasse crime a homofobia. A justificativa para a escolha do tema foi publicada dois dias depois na página da associação na rede social Facebook:

O cenário no Congresso Nacional para os direitos LGBT não tem sido favorável. Por isso é tão urgente e necessário mobilizar a sociedade a favor da vida e da dignidade LGBT. Desta forma, inspirada nas diversas sugestóes recebidas e nas questôes que cerceiam os direitos LGBT, a diretoria da Associação da Parada do Orgulho GLBT escolheu o tema para a XVIII Parada do Orgulho LGBT de São Paulo: "País vencedor é país sem homofobia: Chega de mortes! Criminalização já!". Homofobia mata. E não queremos mais um Brasil campeão em assassinatos e ódio contra LGBT!

Muito obrigado a todos que enviaram as suas ideias!

(Disponível em www.facebook.com/paradasp?fref=ts>, consultado em 15/3/2014)

Alguns dias antes, na mesma página, a associaçáo postou uma nota sobre casos de assassinatos de homossexuais que começava com a seguinte explicação: "O termo homofobia tem como definições a antipatia, desprezo, preconceito, aversão e medo irracional dos LGBTs". Não é possível afirmar que a APOGLBT pretendia "preparar o terreno" para possíveis críticas ao uso generalizado da categoria "homofobia", mas que de alguma forma deixava explícita sua compreensão a respeito do uso da categoria. Entretanto, o tema como um todo, não apenas o uso de "homofobia", seria questionado dias depois.

No dia 29 de janeiro, marcando o Dia da Visibilidade Trans, a ativista Daniela Andrade criou 
uma petição na comunidade Avaaz ${ }^{9}$ reivindicando a mudança do tema. Coloco aqui um recorte da petição "APOGLBT - Associação do Orgulho GLBT de Sáo Paulo: Tomar como tema da parada a lei de Identidade de Gênero (Lei João W. Nery)”.

Por uma parada democrática

O lema de nenhuma das dezessete edições da maior parada do orgulho LGBT do mundo fez referência direta a transexuais ou à transfobia [...]. Apesar de haver quem defenda que o termo "homofobia" abrange "lesbofobia" e "transfobia”, tem ganhado força, especialmente entre travestis e transexuais, o entendimento de que essa palavra ("homofobia") apenas repete uma tendência "gayzista" do movimento, em detrimento dos demais segmentos, menos visíveis. De qualquer forma, a compreensão segundo a qual "homofobia abrange transfobia" não se sustenta se considerarmos o lema da última Parada, "Para o armário nunca mais: União e conscientização na luta contra a homofobia". Como só os homossexuais "discretos", que seguem os padróes heteronormativos, podem se esconder no armário, concluímos que o mote da parada de 2013 excluiu "lésbicas masculinas" e "gays femininos" e a imensa maioria de travestis e transexuais. [...] Ainda é tempo de aprender com os erros do passado. Com o PLC 122 apensado ao anteprojeto de código penal, que por sua vez náo tem previsão de aprovação, é mais do que hora da parada ser dedicada a travestis e transexuais, que constituem o grupo mais vulnerável da sigla e que têm um importante projeto de lei por ser aprovado no Parlamento: o PL 5002/2013 ou Projeto de Lei João Nery. [...] A fim de garantir que a maior publicidade que o movimento LGBT tem a seu dispor seja direcionada para a principal demanda das pessoas travestis e transexuais, reivindicamos que a Associação da Parada do Orgulho GLBT de São Paulo escolha como tema da parada de 2014 "Eu respeito travestis e transexuais e quero a aprovação do Projeto de Lei João Nery!". Começaremos a colher assinaturas hoje, dia 29 de janeiro, dia da vi- sibilidade de travestis e transexuais, até o dia 21 de fevereiro, quando entregaremos pessoalmente a lista de nomes para os representantes da Associação (disponível em secure.avaaz.org/ po/petition/APOGLBT_Associacao_do_Orgulho_GLBT_de_Sao_Paulo_Tomar_como_ tema_da_parada_a_lei_de_Identidade_de_ Genero_Lei_Joao_W_Nery/?pv=2, consultado em 11/3/2015).

As acusaçóes de hegemonia "gay" no movimento LGBT não são novas. $\mathrm{O}$ que é novo nesse fato é a retórica da reivindicação. No percurso do movimento homossexual ao LGBT, as reivindicaçôes de lésbicas, travestis, transexuais e bissexuais seguiram uma lógica de "incluir" ou de "contemplar as especificidades" das diversas identidades coletivas abarcadas pelo movimento (MacRae, 1982; Facchini, 2005; Almeida, 2005; Simóes e Facchini, 2009; Carvalho, 2011). Entretanto, nessa petição não se reivindicava uma ampliação no foco dos holofotes da parada, mas uma mudança de focalização. Com a finalidade direcionar o tema para "a principal demanda das pessoas travestis e transexuais", reivindicava-se que ele fosse: "Eu respeito travestis e transexuais e quero a aprovação do Projeto de Lei João Nery!".

A princípio, a disputa pelo proscênio, ou melhor, pelo lugar de destaque no cartaz do espetáculo, é operada nos bastidores, compostos de reunióes da diretoria da APOGLBT e "diversas sugestóes recebidas" por ela. Entretanto, o mesmo bastidor foi transformado em palco quando a decisão a respeito do roteiro do espetáculo foi colocada em questão. O recurso cênico fundamental nessa transformação foi o uso das redes sociais da internet como forma de democratização da participação política. Nas semanas que seguiram a criação da petição, diversos/ as ativistas trans participaram de uma campanha online pela alteração do tema da parada.

Em resposta à petição e a essa campanha, a APOGLBT publicou no dia 11 de fevereiro a seguinte nota:

Como tem sido feito todo ano, a Diretoria da Associação tira uma diretriz que deve nortear o tema da Parada. Desde o ano passado tem sido 
consenso que o tema seria focado na criminalização das condutas que agridem, discriminam e tiram a vida de tantos gays, lésbicas, travestis, transexuais e bissexuais no nosso País. Por isso já tiramos o tema que será "País vencedor é País sem Homofobia. Chega de Mortes! Criminalização Já!" que é abrangente e contempla a comunidade LGBT. Foi aberto inclusive para sugestóes que trouxessem a criminalização da homofobia e foi publicamente, sendo aproveitado sugestóes que abordavam o tema. Não obstante a isso entendemos toda a dificuldade que as transexuais sofrem e nos solidarizamos como com a luta dos gays e lésbicas. Não temos como mudar o tema da $18^{\mathrm{a}}$ Edição da Parada porém nos comprometemos a buscar subsídios junto à Prefeitura e Governo do Estado para termos um trio para visibilizar a Lei João Nery que busca aprovação.

Diretoria da Associação da Parada do Orgulho GLBT - APOGLBT

(Disponível em www.facebook.com/paradasp?fref=ts, consultado em 15/3/2012, grifo nosso)

Essa resposta foi fortemente criticada nas redes sociais da internet, não apenas por pessoas trans como também por diversos/as ativistas identificados com o movimento LGBT. Com o acirramento dos ânimos, a APOGLBT organizou uma reunião com ativistas trans no dia 19 de fevereiro. Após uma longa discussão chegou-se a um consenso e o tema da 18 a Parada do Orgulho LGBT de São Paulo passou a ser: "País vencedor é país sem HomoLesboTransfobia: Chega de Mortes! Criminalização Já! Pela aprovação da Lei de Identidade de Gênero!"10

Assim, a maior parada do orgulho LGBT do mundo mudou seu tema. A retirada das disputas dos bastidores, para colocá-las em cena no palco das redes sociais da internet, produziu por si só uma manobra nos holofotes. Independentemente do que de fato aconteceu até o dia 4 de maio, quando a parada foi realizada, a própria disputa lançou luz não apenas sobre o "Projeto de Lei de Identidade de Gênero", mas também foi capaz de produzir ou reiterar um regime de visibilidade trans no qual essas pessoas se configuram como as principais vítimas de violência letal, assim como outro regime no qual elas/es são apresentadas/os como ativistas minorizadas/os ou periféricas/os no movimento LGBT. ${ }^{11}$

A comemoração com a mudança no tema da parada não durou muito. Entre os dias 22 e 25 de abril, no auditório do Sindicado dos Comerciários (região central de São Paulo), aconteceu o "120 Ciclo de Debates do Mês do Orgulho LGBT de São

Figura 1

Campanha nas Redes Sociais pela Alteraçáo do Tema da 18 a Parada do Orgulho LGBT de Sáo Paulo
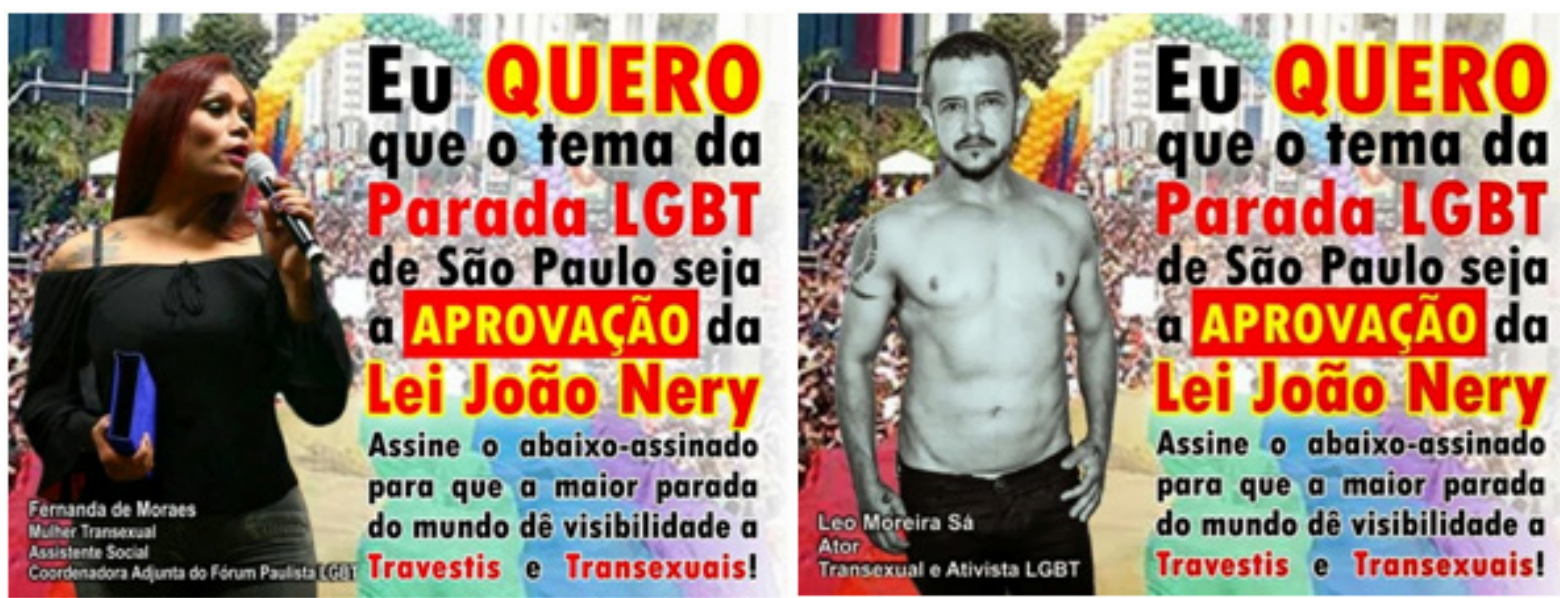

Fonte: acervo da pesquisa "Muito prazer, eu existo!" Visibilidade e reconhecimento no ativismo de pessoas trans no Brasil (Carvalho, 2015). Memes publicados por diferentes páginas e perfis no Facebook. 
Paulo". Ao acessar a programação, notava-se a ausência de qualquer debate que tratasse diretamente de pessoas trans. Seguindo a ordem cronológica, as mesas de debate tiveram os seguintes temas: "A homossexualidade sob a ótica das religiôes"; "O bullying homofóbico no contexto escolar"; "Homossexualidade e a inclusão corporativa"; e "As paradas e nossas conquistas". Chegando ao auditório do Sindicato dos Comerciários, encontrava-se a seguinte faixa (Figura 2).

A primeira impressão foi duvidar da real mudança no tema da parada, pois demorei a notar que a menção à Lei de Identidade de Gênero estava na parte superior, deslocada do restante do tema e com grafia errada ("gêneros" em vez de "gênero"). Essa percepçáo foi reiterada numa conversa com um ati-

Figura 2

Faixa de Divulgaçáo do $12^{\circ}$ Ciclo de Debates do Mês do Orgulho LGBT de Sáo Paulo

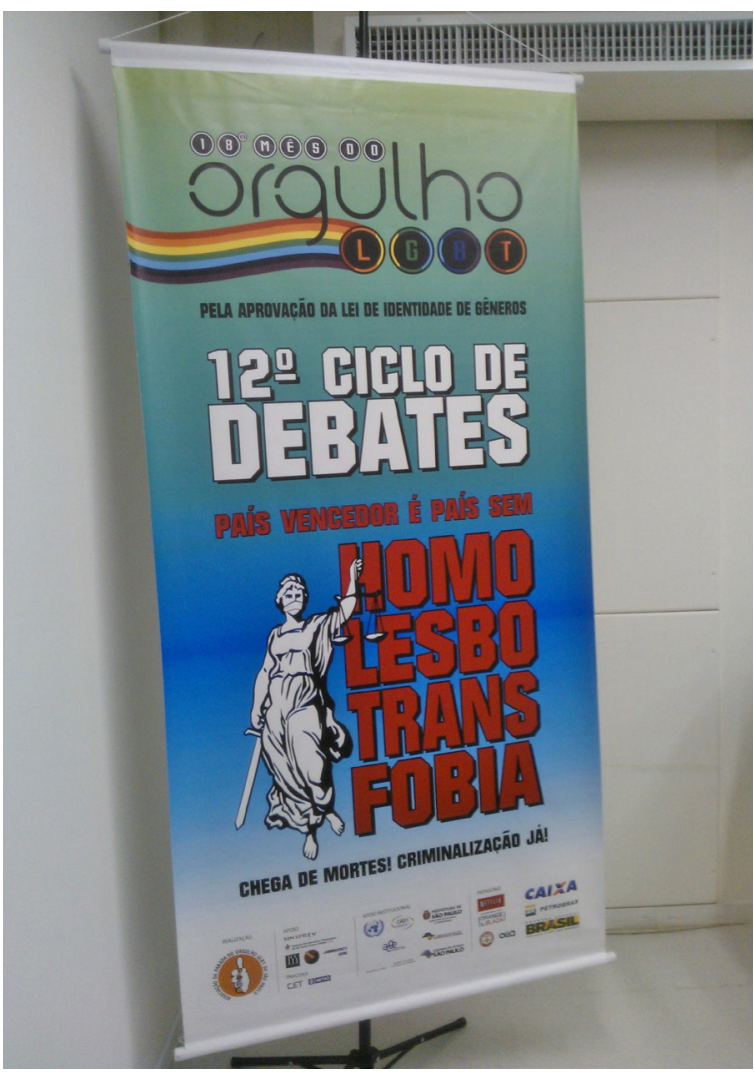

Fonte: acervo da pesquisa "Muito prazer, eu existo!" Visibilidade e reconhecimento no ativismo de pessoas trans no Brasil (Carvalho, 2015). Foto do autor. vista trans presente em um dos debates, apontando para a faixa, ele me dizia:

"Mudou, mas pela metade. Olha ali a frase bem pequenininha."

Então questiono: "Mas por que você acha que foi assim?”

"Na cabeça dos gays, e você sabe disso, não existem transexuais, só homossexuais. Para o movimento LG só há orientação sexual. Eles não entendem a existência de identidades de gênero. Aí, aceitar mudar o tema é lutar por uma coisa que eles não acreditam" (Diário de campo, 24/4/2014).

A polêmica sobre a mudança no tema da parada apareceu apenas no último dia do ciclo de debates ("As paradas e nossas conquistas"). Nessa noite, um dos fundadores da APOGLBT falou: "a reivindicação das trans ${ }^{12}$ é válida, mas no final todos perdemos, porque ninguém ficou em evidência depois dessa junção de temas" (grifo nosso).

Nas disputas entre as identidades coletivas que compóem o movimento LGBT, a ideia de "todos" é facilmente confundida com a de hegemonia gay. $\mathrm{Na}$ afirmação citada, "todos perdemos" é, em certo sentido, "nós, gays, perdemos", pois na versão anterior do tema da parada não havia nenhuma menção direta ou indireta às reivindicaçóes de ativistas trans, que já não estavam em "evidência”. A impossibilidade de uma saída satisfatória passa por uma disputa pelo proscênio cuja ocupação parece não poder ser nem compartilhada nem alternada.

Outra problemática apresentada nessa afirmação é a noção de "evidência". Na petição articulada por ativistas trans, a parada é descrita como "a maior publicidade que o movimento LGBT tem ao seu dispor". A visibilidade massiva da Parada do Orgulho LGBT de São Paulo ${ }^{13}$ configura-se como uma "publicidade" disputada. No caso, os/as ativistas trans desejavam que a mesma fosse "direcionada a principal demanda de pessoas travestis e transexuais". Nesse sentido, uma "publicidade direcionada" proporcionaria "evidência" a uma determinada questão, ou melhor, a um determinado grupo de 
Figura 3

\section{Traseira do Quinto Trio Elétrico da 18 ${ }^{a}$ Parada do Orgulho LGBT de Sáo Paulo}

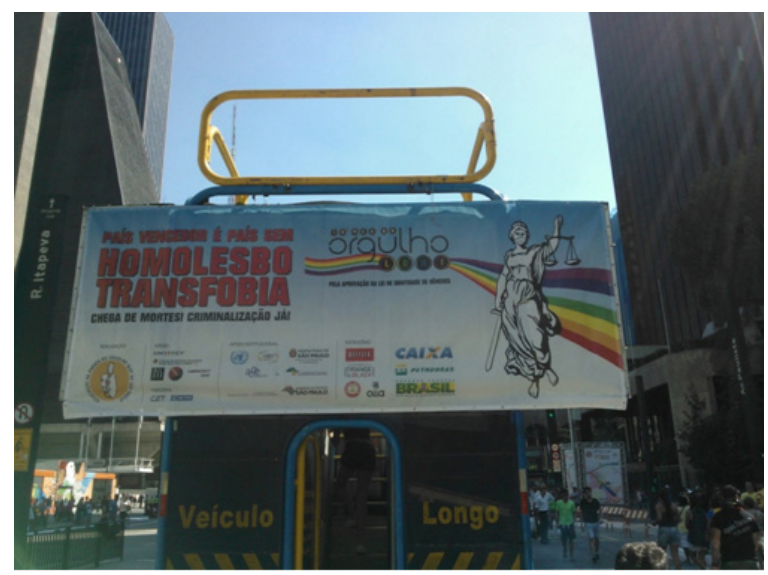

Fonte: acervo da pesquisa "Muito prazer, eu existo!" Visibilidade e reconhecimento no ativismo de pessoas trans no Brasil (Carvalho, 2015).

pessoas, pois, em virtude da práxis identitária hegemônica no movimento LGBT, questóes e demandas políticas emergem das especificidades das categorias identitárias oficialmente reconhecidas, de maneira que evidenciar uma questão seria evidenciar um tipo de pessoa. Considerando a impossibilidade de direcionar essa publicidade a um grupo específico, ainda que se possa advogar que o primeiro tema proposto já fazia isso, a APOGLBT oferece um "trio para visibilizar a Lei João Nery". Nega-se a publicidade direcionada, mas se oferece alguns minutos de "evidência". Não resolvida a questão, constrói-se um tema a partir de um híbrido de pautas políticas que na ausência de foco, "ninguém ficou em evidência".

No domingo, 4 de maio, chego à avenida Paulista por volta do meio dia. Vários trios elétricos já estavam posicionados ao longo da avenida. Para ter uma ideia mais geral da visualidade da parada, resolvo caminhar a partir do primeiro trio até o final. ${ }^{14}$ Já nos primeiros trios elétricos percebia-se que a identidade visual ou os cartazes oficiais do espetáculo minorizavam a reivindicação de ativistas trans. No final, pouca coisa ou quase nada mudou no tema da parada, como é possível perceber na Figura 3.
Nota-se que a menção "pela aprovação da lei de identidade de gêneros" [sic] é quase imperceptível, aparecendo logo abaixo de "orgulho LGBT" e náo conjuntamente com o tema da parada. Essa foi a identidade visual utilizada em todos os trios oficiais da APOGLBT. ${ }^{15}$

Chegando a posição na qual deveria estar o décimo trio, surpreendo-me com a sua ausência. Sem saber o que de fato estava acontecendo, caminho pelos arredores de onde deveria estar o trio da "Visibilidade Trans" e encontro um grupo de jovens com uma faixa confeccionada a mão, na qual se lia: "Pela aprovação do PL 5002/13 João Nery pela Identidade de Gênero". Esse grupo havia se organizado através da convocação feita pela "Frente LGBT* da USP”, nas redes sociais, para uma reuniâo que foi realizada dois dias antes da parada, na Faculdade de Filosofia, Letras e Ciências Humanas da Universidade de Sáo Paulo (FFLCH-USP):

CONVOCATÓRIA - Bloco de Unidade na Parada LGBT de SP: Pela Aprovação da Lei João Nery!

Historicamente, o movimento LGBT se centrou quase que exclusivamente em torno das pautas de homens gays, pesando-se as iniciativas pioneiras e exceçóes. [...] Prova disso é o fato da Parada ser mais conhecida como "Parada do Orgulho Gay”, sem inclusão das outras categorias.

Esse ano, após uma grande mobilização pela mudança do tema e da exigência atendida por reunióes presenciais de diálogo, um acordo com a Associação da Parada do Orgulho LGBT de Sáo Paulo teria conseguido mudar o tema da Parada de 2014 para incluir uma menção expressa ao PL João Nery de Identidade de Gênero e à transfobia específica [...]. No entanto, de surpresa, descobrimos que o material de divulgação da Parada ignora este acordo e não o colocou em prática, desrespeitando tanto a pauta em si como a mobilização que pensamos vitoriosa em mudar isso!

Nesse sentido, a Frente LGBT* da USP decidiu convidar todos os coletivos, grupos, or- 
ganizaçóes e militantes LGBT* individuais de todas as regióes da cidade, e quem mais quiser somar, para construir um bloco de unidade, para ir à Parada como uma intervenção unitária pela Aprovação da lei João Nery e para denunciar tanto tal ataque da Associação como para pautar a 'questão' trans*! Com nossas faixas, cartazes e batucadas, explicitaremos o espaço da Parada como espaço de disputa política para as pessoas LGBT*!

Chamamos, assim, uma reunião de construção desse bloco para o dia $30 / 4$, às $17 \mathrm{~h} 30$ no prédio das Ciências Sociais na USP, reiterando que o convite se estende para toda e qualquer organização e militantes com interesse em pautar a questão trans* de forma ativa durante a Parada em SP!

Vai ser tiro, porrada e bomba! Vem pro ataque!

(Disponível em www.facebook.com/FrenteLgbttUsp/ photos/a.524494540923259.1073741830.5233 $82334367813 / 688105434562168 /$ ?type $=1 \&$ stre am_ref=10, consultado em 12/3/2015).

Após essa reunião, assinavam a convocação para o bloco: deputado Jean Wyllys, Frente LGBT* da USP, Frente LGBT da FMU, PUC Purpurina, Coletivo RUA - Juventude Anticapitalista LGBT, Juntos LGBT, Setorial LGBT do Partido Socialismo e Liberdade de São Paulo (Psol-SP), Igreja da Comunidade Metropolitana, Centro Acadêmico Guimarães Rosa (Instituto de Relaçóes Internacionais da USP), Centro Acadêmico de Filosofia da USP e o Diretório Central dos Estudantes da USP (DCE Livre Alexandre Vannucchi Leme).

Tendo essas informaçóes, ${ }^{16}$ foi mais fácil compreender a presença majoritária de jovens do movimento estudantil. Uma parte significativa dessas pessoas tinha algum tipo de ligação, orgânica ou de simpatia, com o Psol. Alguns usavam um adesivo que tinha uma bandeira do movimento trans ao fundo, a reivindicaçáo pela aprovação do Projeto de Lei João Nery, e a assinatura do Insurgência, grupo interno do Psol.

Havia um subtexto nessa história que remetia a uma disputa entre integrantes do Partido dos Trabalhadores (PT) e do Psol a respeito de qual parti- do político melhor representaria as pautas LGBT. Uma parte da diretoria da APOGLBT seria filiada ao PT, e alguns dos integrantes desse "bloco" na parada acusavam essas pessoas de não quererem dar visibilidade ao referido Projeto de Lei por ele ter sido proposto por um parlamentar do Psol. Tais discursos acusatórios diziam que a ausência do trio da "Visibilidade Trans" seria um "golpe" da APOGLBT, que não queria dar destaque ao deputado federal Jean Wyllys, que viria nesse trio. Por outro lado, uma ativista trans ligada ao PT, que também estava próxima à concentração desse bloco, disse que, segundo a diretoria da APOGLBT, teria havido algum tipo de irregularidade no trio que impossibilitou sua utilização. É praxe nas Paradas do Orgulho LGBT de São Paulo que todos os trios passem por uma vistoria do Corpo de Bombeiros antes de entrarem na avenida Paulista, náo sendo raros os casos de trios que na última hora são impossibilitados de participar da parada em virtude do não cumprimento de alguma norma de segurança. Fato foi que não existiu um trio da "Visibilidade Trans".

Algumas ativistas trans pareciam já antecipar uma invisibilização de sua demanda na parada. Usando seus corpos como cartaz numa representação que subentendia uma visibilidade imediata dos corpos trans, elas "roubavam a cena":

Ao longo do percurso da parada, o bloco foi crescendo com a presença de mais ativistas trans, do deputado federal Jean Wyllys e do próprio João W. Nery. Ao final da parada, o clima entre as principais lideranças trans da capital paulista era de revolta. Duas delas conversavam:

"Por que só o trio das trans não saiu?"

"E olha que pelo segundo ano seguido! Quero só ver o que eles vão dizer agora! Foi uma palhaçada!"

"Não vamos ficar caladas!"

"Aí tem ekê, mona!"

(Diário de campo, 4/1/2014)

A revolta era esperada pela quebra no script do espetáculo tal qual pactuado nos bastidores. As respostas autônomas geraram um espetáculo dentro de outro, ou uma tentativa de roubar a cena. Entretanto, os poderes materiais e simbólicos do grande 
Figura 4

Ativistas Trans na $18^{\text {a }}$ Parada do Orgulho LGBT de São Paulo ${ }^{18}$
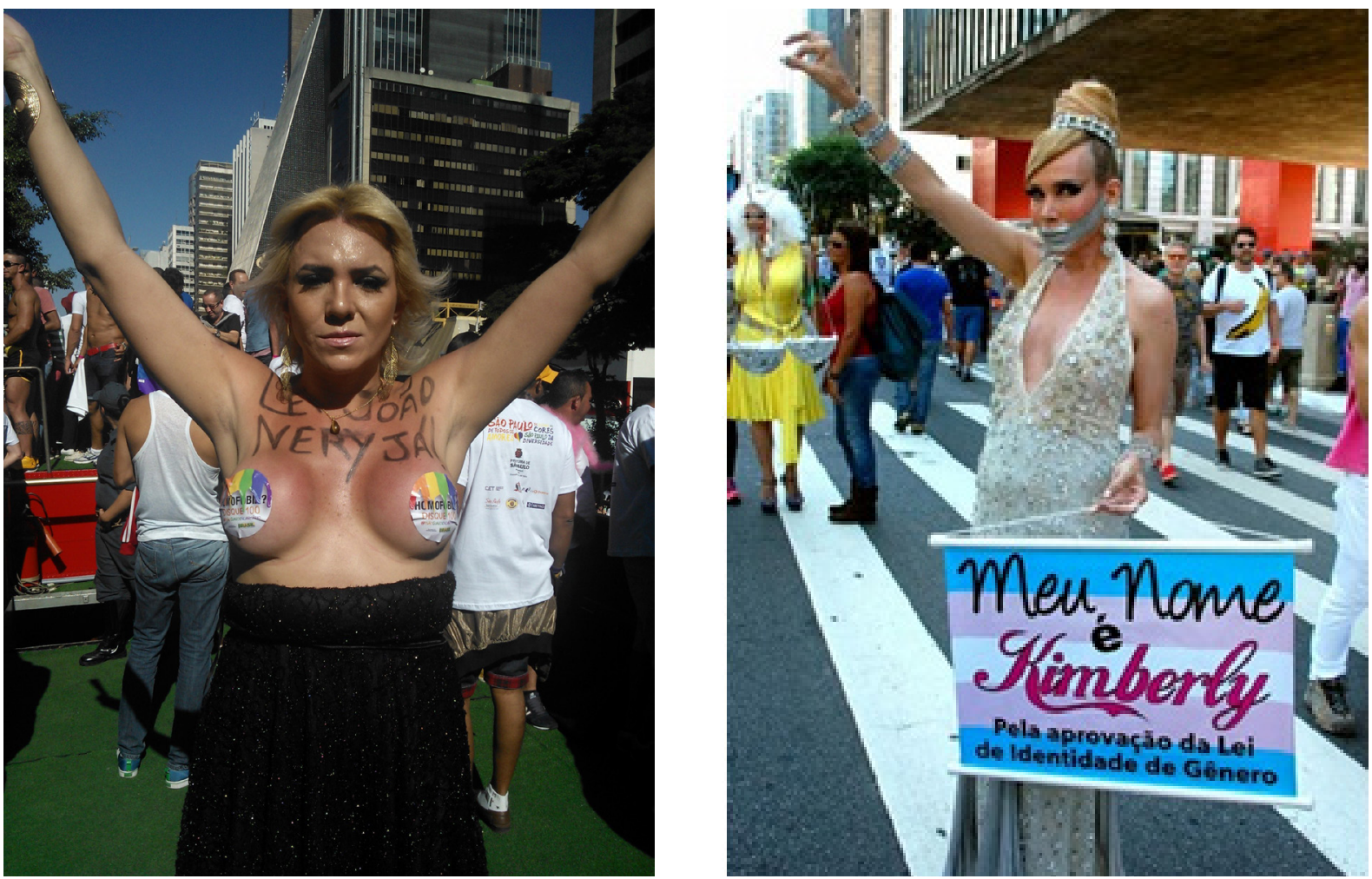

Fonte: acervo da pesquisa "Muito prazer, eu existo!" Visibilidade e reconhecimento no ativismo de pessoas trans no Brasil (Carvalho, 2015).

espetáculo impossibilitam grandes holofotes para os/as dissidentes. Em certo sentido, os acontecimentos em torno da 18 a Parada do Orgulho LGBT de São Paulo remetem às relaçóes de intrusividade do estigma travesti na luta pela construção de uma identidade gay respeitável. Lembro, então, de dois acontecimentos.

O primeiro foi durante as intervençóes do então chamado Movimento Homossexual Brasileiro nos debates da Assembleia Nacional Constituinte em 1987. Cristina Câmara (2002), analisando a trajetória do grupo Triângulo Rosa, nos conta:

João Antônio de Souza Mascarenhas esteve como membro do Triângulo Rosa e participante do movimento gay, proferindo palestras nas plenárias das Subcomissóes dos Direitos e Garantias Individuais, e na dos Negros, Populaçóes Indígenas,
Pessoas Deficientes e Minorias, respectivamente, em 20 de maio e 24 de junho de 1987. Nas duas ocasióes, afirmou que haveria na sociedade uma confusão entre o homossexual e o travesti, o que para o movimento gay seria um grande erro. Há, segundo ele, o homossexual comum e há o travesti, que em muitos casos são prostitutos e acabam se envolvendo com pequenos furtos ou drogas. A imagem predominantemente atribuída ao homossexual, na verdade corresponderia ao travesti e esta aproximação atrapalharia o movimento organizado (Câmara, 2002, p. 57).

O segundo acontecimento foi no processo de construção da ABGLT (Associação Brasileira de Lésbicas, Gays, Bissexuais, Travestis e Transexuais). ${ }^{19}$ Nesse momento, já existiam as primeiras organizaçôes de travestis no Brasil. ${ }^{20}$ Em 1995, na 
cidade de Curitiba, durante o VIII Encontro Brasileiro de Gays e Lésbicas, foi fundada a ABGLT. Entretanto, a presença da letra "T" na sigla da entidade não foi um processo automático nem consensual. Jovanna Cardoso, fundadora da primeira ONG de travestis no Brasil, participou desse processo e relata as dificuldades enfrentadas:

Eles [gays e lésbicas] não queriam por hipótese alguma colocar o T. Aí, a partir de lá, que nós brigamos e conseguimos aprovar o $\mathrm{T}$. Aí a partir daí que as travestis começaram a participar... e ainda de forma tímida, e ainda muito discriminadas. A gente ia para os eventos e eles nos discriminavam. Eles ficavam de longe apontando na hora que a gente ia comer, na hora do café da manhã. Não queriam dividir apartamento, náo queriam sentar na mesma mesa do café, do almoço, do jantar (Jovanna Baby, entrevista em 18/6/2010, apud Carvalho, 2011, p. 31).

Em ambas as situaçóes há uma tentativa de distanciamento entre as identidades "gay/homossexual", de um lado, e "travesti/trans", de outro. As compreensōes sociais que tecem relaçóes entre "um desejo sexual por homens" e "um desejo por ser mulher" parecem gerar uma reação de total apartamento entre as duas enunciaçóes (sintetizadas de certa forma nas identidades "gay" e "travesti" ou "transexual"). O processo de diferenciação, por sua vez, implica na construção de uma barreira que impede a intrusão de um estigma, gerando, assim, uma hierarquia de indesejados/as, na qual as travestis estariam no topo. A soluçáo encenada na parada foi apagar os holofotes sobre atores e atrizes cuja interferência cênica pudesse comprometer o espetáculo da respeitabilidade ou a respeitabilidade do espetáculo. Retomarei essa discussão ao final deste artigo; entretanto, antes de seguir para o segundo ato, no palco carioca, um interlúdio se faz necessário: a internet.

\section{Um interlúdio: a internet}

Há na literatura uma grande discussão topográfica sobre a internet que por vezes caminha num sentido de separaçáo espacial de um universo offli- ne/real/presencial de um universo online/virtual/à distância. É no seio dessa discussão que surgem categorias como "ciberespaço", a qual visa circunscrever eventos, interaçóes, identidades e discursos produzidos online a um espaço específico, passível de delimitação teórica e analítica. ${ }^{21}$ Entretanto, os avanços contínuos das tecnologias e das possibilidades de acesso à internet constroem um cenário no qual tal separação se torna problemática tanto do ponto de vista teórico quanto analítico. Algumas caracterizaçóes e previsôes sobre os potenciais de transformação social, cultural e política da internet, feitas há menos de uma década, soam por vezes anacrônicas principalmente quando não se poderia prever as possibilidades de acesso remoto (com o advento dos smartphones) e as reformulaçôes no funcionamento da própria internet..$^{22}$ Aqui me refiro ao debate sobre o caminho para uma tecnologia voltada para maiores possibilidades de interação, cooperação e conexão nas mudanças de funcionamento da internet que são comumente, embora não consensualmente, caracterizadas como Web 1.0, Web 2.0 e Web 3.0. Segundo Carolina Parreiras:

[...] as tecnologias da Web 1.0 permitem "processos cognitivos de comunicação", sendo que há uma relação do usuário com o hipertexto. Já a Web 2.0 cria bases para "processos comunicativos", utilizando, para tal, plataformas interativas como as redes e mídias sociais. Por fim, a Web 3.0 teria como fundamento permitir os "processos cooperativos", realizando a integração de dados para construir novas informaçōes e significados (Parreiras, 2015, pp. 29-30).

Já no encontro com os estudos de movimentos sociais, ativismos e engajamento político, outra polêmica se apresenta: o caráter revolucionário da internet para as açôes políticas. Esse debate passa por posiçóes otimistas que, principalmente a partir de experiências como a Primavera Árabe e o Occupy, sinalizam o grande potencial de articulaçáo, mobilização e deliberação a partir dos usos políticos das redes sociais da internet (Castells, 2013), até posiçóes pessimistas que marcam a ilusão democrática e de liberdade presente em tais práticas frente a grande 
força de agencias governamentais e grandes corporaçóes no controle dos dados e na vigilância constante sobre os usos e práticas na internet (Morozov, 2011). A grande maioria dessas análises tem como campo empírico grandes manifestações de massa e, enquanto o polo otimista ressalta que a adesão massiva a tais manifestaçóes/revoltas/levantes só se fez possível por um uso sistemático das redes sociais da internet, o polo pessimista ressalta que as conquistas resultantes de tais eventos só foram possíveis pela presença material de milhares (em alguns casos milhóes) de corpos em praça pública. ${ }^{23}$

Creio que essa polarização guarda implicitamente não apenas a separação onlinel offline, e a consequente valorização de um "espaço" ou outro para a ação política, como também a relação entre tecnologia e sociedade. Para Nancy Baym (2010), essa relação pode ser pensada como: 1) um determinismo tecnológico que molda a sociabilidade e consequentemente a ação política; 2) uma construção social da tecnologia que enfoca o surgimento da tecnologia a partir dos processos sociais; 3) um meio-termo entre essas duas posições, enfatizando a influência mútua entre tecnologia e sociedade (vertente chamada de social shaping); 4) uma domesticação tecnológica que faz da tecnologia algo imerso no cotidiano social (vertente que se aproxima do social shaping).

Nesse sentido, tanto o social quanto a própria internet compóem uma relação complexa de múltiplos vetores de influência na qual a busca por determinaçóes simplistas nublam a complexidade dos fenômenos sociais e políticos imbricados pela tecnologia, em outras palavras, trata-se de "mapear as conexôes relevantes sem determinaçôes simplistas" (Rohden, 2012, p. 52). Parte desse problema reside na definição do objeto e do contexto de pesquisa. Seria possível pensar que o ativismo trans seria o objeto dessa pesquisa, enquanto a internet seria o contexto, ou vice-versa. Entretanto, a questão é um pouco mais complexa, como apresentam Daniel Miller e Don Slater (2004, p. 46):

Deve ficar claro que o compromisso etnográfico de "colocar as coisas no contexto" precisa evitar o perigo de reificar o objeto tanto quanto evitar o perigo de produzir um contexto reificado analiticamente. Isso significa desagregar "a internet" na profusão de processos, usos e "tecnologias" sociais que ela pode compor em diferentes relações sociais ao invés de considerá-la como um "objeto" único com propriedades inerentes que podem, no máximo, ser expressos de formas variadas em diferentes contextos. Novamente, esse assunto transcende a distinção entre online e offline. [...] Diferentes circunscriçóes do objeto e do contexto surgem através dos seus inter-relacionamentos observados.

O objeto da pesquisa apresentada é o ativismo trans, entretanto, definir "a internet" ou "a rua" como um contexto geral e uniforme seria um erro. Parafraseando os autores, tais espaços da internet podem ser entendidos como produtos do ativismo trans, justamente como o ativismo trans está se tornando um produto, entre outras coisas, de tais espaços e usos da internet. Analogamente, a ocupação da rua por manifestantes pode ser entendida como um produto da internet, assim como a internet está se tornando um produto, entre outras coisas, da ocupação da rua por manifestantes. Apresenta-se a necessidade de compreensão analítica dessa relação num continuum onlineloffline (Beleli, 2012; Miskolci, 2016), o que transforma o contexto em algo que extrapola a internet para o campo mais amplo dos ativismos relacionados a dissidências/ desvios/estigmas de gênero e sexualidade.

Feitas essas consideraçóes, passo ao segundo ato. Os recortes etnográficos apresentados na sequência não apenas evidenciam as relaçóes apresentadas acima, como sugerem outra: a ocupação política das ruas e o ativismo trans.

\section{Ato pelo Dia Nacional da Visibilidade Trans - Rio de Janeiro}

$\mathrm{O}$ ato "\#Respeito, do morro ao asfalto, travestis e transexuais existem de fato!", convocado pelo grupo TransRevolução ${ }^{24}$ com apoio de outros coletivos (Pela Vidda-RJ, Marcha das Vadias e BeijATO) tinha sua concentração marcada para às 17 horas nas escadarias da Câmara dos Vereadores do Rio de Janeiro, situada na Cinelândia, região central da cidade. Porém, por causa da presença de muitos 
ativistas em outras atividades do dia, ${ }^{25}$ boa parte dos/ das participantes chegou por volta das 19 horas.

O manifesto de convocação para o ato, que constava como descrição no evento criado para sua divulgação no Facebook, marcava que a data seria mais para reivindicaçóes que para comemoraçóes. Com a chamada "Contra a TRANSFOBIA, nossa luta é todo dia!", o manifesto apresentava três denúncias centrais da precariedade da situação social de pessoas trans no Brasil: 1) alto índice de assassinatos de travestis e transexuais; 2) exclusão do mercado de trabalho formal; 3) dificuldade no acesso aos serviços de saúde do Processo Transexualizador no Sistema Único de Saúde (SUS). ${ }^{26}$ Não havia, portanto, nenhuma novidade com relação às reivindicaçôes, com exceção da ausência de menção ao Projeto de Lei João Nery, carro-chefe das reivindicações na $18^{a}$ Parada do Orgulho LGBT de São Paulo.

Ao final do manifesto convocava-se para que, no dia anterior (28/1/2015), o ato e a importância do Dia da Visibilidade Trans fossem divulgados nas redes sociais com o uso de \#RespeitoJeSuis Travesti e \#RespeitoJeSuisTrans, que acabaram sendo mais utilizados como \#JeSuis Travesti e \#JeSuis Trans. ${ }^{27}$ Essa estratégia foi utilizada numa clara alusão ao uso de \#JeSuisCharlie e \#JeNeSuisPasCharlie como manifestaçóes de apoio ou de repúdio ao jornal satírico francês Charlie Hebdo, em virtude do ataque terrorista sofrido em 7 de janeiro de 2015.

As novidades estavam também nas articulações políticas para a realização do ato. Em atos como esse, o apoio de outros grupos e ativistas é representado em diversos momentos quando se necessita que algum trabalho manual seja executado. Tais trabalhos compreendem: prender uma faixa, garantir que a aparelhagem de som esteja funcionando adequadamente, distribuir panfletos para as pessoas que passam na rua, ajudar a acender velas, entre outros. Esses atos compóem uma cena na qual as atrizes e os atores coadjuvantes encenam seu apoio, executando diversas tarefas para a boa condução do espetáculo sem ocupar o proscênio. Apresento, então, as três alianças mais claras no ato em termos de equipes coadjuvantes.

A primeira parceria, já esperada, era com o grupo Pela Vidda-RJ. Nessa equipe, encontravam-se, além de pesquisadores do campo da AIDS,

agentes comunitários de saúde, representantes de conselhos de saúde e agentes de prevenção. Através dessa interlocução, foi possível garantir uma sala dentro de um equipamento de saúde próximo que serviu como camarim para as pessoas que iriam realizar performances. Havia também, desde a concentração para o ato, uma estrutura montada para realização de testes rápidos de HIV via fluido oral.

A segunda equipe em cena era um grupo de ativistas da Marcha das Vadias. ${ }^{28}$ Usando camisetas lilás com o símbolo do transfeminismo, ${ }^{29}$ que representavam uma cena dupla de engajamento político. Por um lado, se o coletivo Marcha das Vadias reivindica o transfeminismo em oposição a outros feminismos, tal posicionamento teria de ir além de manifestos e da aceitaçáo da presença de pessoas trans no coletivo, para se configurar em presença cênica no palco privilegiado das reivindicaçóes trans. Por outro lado, a presença dessas ativistas sinalizava a existência do transfeminismo como uma epistemologia feminista mais coerente para a luta política que ali se encenava.

Figura 5

Símbolo do Transfeminismo

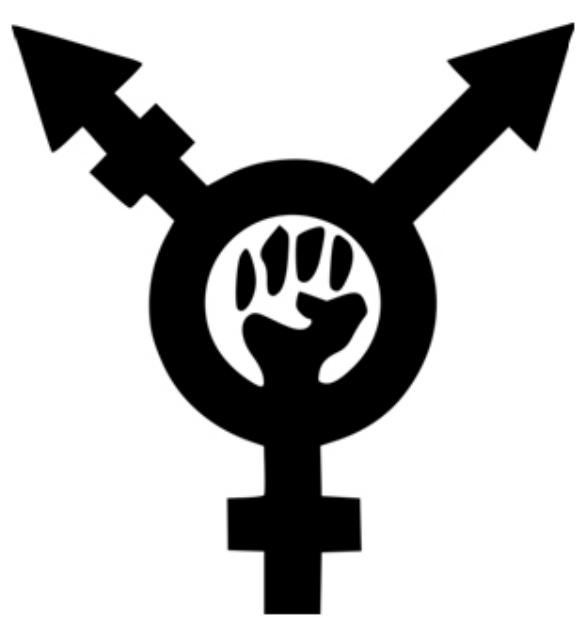

Fonte: acervo da pesquisa "Muito prazer, eu existo!" Visibilidade e reconhecimento no ativismo de pessoas trans no Brasil (Carvalho, 2015). 
Em virtude de sua composição hegemonicamente juvenil, a Marcha das Vadias também traz para o espetáculo do ato outros recursos cênicos que não são comuns ao ativismo trans. $\mathrm{O}$ mais notável deles foi o uso de pichações no chão da Cinelândia como forma de marcar a manifestação para além do momento de sua realização, ao se deixar marcas no espaço urbano para prolongar a mensagem no tempo e no espaço.

A terceira equipe em cena era um grupo chamado BeijATO. Segundo um interlocutor, a BeijATO se autodefine como "uma coletiva transfeminista e glitterterrorista". ${ }^{30}$ Esse grupo surgiu a partir de uma reuniáo para organizar um "beijaço" ${ }^{11}$ que seria realizado em virtude da vinda do Papa Francisco para a Jornada Mundial da Juventude, em 2013. Essa reunião foi realizada nas dependências do Instituto de Filosofia e Ciências Sociais da Universidade Federal do Rio de Janeiro (IFCS-UFRJ). O grupo de composição majoritariamente estudantil teve suas açôes também fortalecidas em virtude da organização, no Rio de Janeiro, da campanha mundial "Para Rússia com Amor" ("To Russia with Love"), que reivindicava o fim da lei que proíbe "propaganda da homossexualidade", apoiada pelo presidente russo Vladimir Putin. Nesse caso, o beijaço foi a dramaturgia escolhida para as manifestaçóes realizadas na frente de consulados e embaixadas russas pelo mundo.

Não é possível restringir as ações do grupo a esses dois beijaços. Ele surgiu em meio às manifestaçôes de junho de 2013, em conexóes com ativistas da Marcha das Vadias e com novas expressóes de ativismo LGBT, como, por exemplo, os pink blocs (uma versão "gay" satírica e bem-humorada dos black blocs $^{32}$ ). As/os ativistas desses grupos se misturavam em estratégias internas às manifestaçôes e em açóes conjuntas quanto a questóes relacionadas a gênero e sexualidade. Assim, nos protestos em oposição ao então governador Sérgio Cabral, em resposta aos gritos de "Ei, Cabral, vai tomar no cu!", estes/estas ativistas gritavam: "Ei, Cabral, toma da polícia! Porque tomar no cu, te garanto, é uma delícia!". Outras estratégias, que simultaneamente reivindicam o estigma e o reformulam como ferramenta política, eram também utilizadas. Os pink blocs substituíram o coquetel molotov dos black blocs por glitter, dando origem ao uso do termo "glitterterrorismo". ${ }^{33}$ A lógica dessa estratégia seria espalhar glitter pelas pessoas e lugares públicos como uma forma de deixar as marcas do estigma da homossexualidade, ou da "viadagem", o que foi feito nos muros do Consulado da Rússia no Rio de Janeiro.

No dia 29 de janeiro de 2015, os/as ativistas do BeijATO caminhavam com sacolas de plástico cheias de pequenos pedaços de papel dobrados e pediam para as pessoas pegarem um deles. Em cada um lia-se na parte externa frases como: "sou filha, eu existo", "sou negra, eu existo", entre outras semelhantes. Na parte interna, constava o nome de uma travesti ou transexual assassinada em 2014 e a forma como foi assassinada, por exemplo: "Camila Veronesi, transexual, assassinada a tiros. Não existo mais". Dessa forma, buscava-se sensibilizar a plateia para o drama encenado. A informação sobre a condição de travesti ou transexual só era revelada após uma informaçáo que igualava aquelas pessoas a outras, como se primeiro se conferisse o estatuto de humano para depois denunciar a sua quebra, por meio de assassinatos cruéis em virtude da travestilidade ou da transexualidade.

Nesse cenário, a ativista Indianara Siqueira possivelmente se configura como um elo entre diferentes equipes. Sua formação ativista se deu conjuntamente com a construção da resposta a epidemia da Aids na cidade de Santos. ${ }^{34}$ No final da década passada, já morando no Rio de Janeiro, se juntou ao TransRevoluçáo e consequentemente aos trabalhos do Pela Vidda-RJ. Sua participação na Marcha das Vadias, no movimento de prostitutas e nas manifestaçóes de junho de 2013 a aproximou de outros grupos, como o BeijATO.

$\mathrm{O}$ ato teve duas drag queens como mestras de cerimônia. Aconteceram algumas performances de travestis, drag queens e transformistas. Entre estas, a que chamou mais atenção da plateia e acabou sendo cantada por muitas das pessoas presentes foi feita com a canção "Brasil”, de Cazuza. Interpretada por uma travesti negra com um vestido de cabaré dos anos de 1930 em verde e amarelo, a artista transformava a letra da canção no enredo diário de uma travesti. Essas apresentações foram entremeadas por discursos de ativistas do TransRevolução 
que reafirmavam as reivindicaçóes expressas no manifesto. Também foram feitos discursos defendendo a aprovação do PL João Nery.

De maneira geral, a impressão era de um ato muito maior do que o que havia presenciado em janeiro de 2013. Ainda assim, para o meu olhar, esse aumento decorria mais de uma diversificação nas alianças e articulaçóes políticas que o grupo TransRevolução foi capaz de fazer nos últimos anos do que de um aumento na quantidade de ativistas trans - mas eu estava errado. Um dos últimos ativistas a discursar foi Leonardo Peçanha, à época membro do TransRevolução e coordenador do Instituto Brasileiro de Transmasculinidades (Ibrat), principal organização de homens trans em âmbito nacional. Ele subiu a escadaria e, ao microfone, foi chamando um nome depois de outro. Como se fossem atores escondidos na plateia, vários rapazes começaram a subir as escadarias e se posicionam lado a lado. Em seu discurso, Leonardo marcou a invisibilidade dos homens trans e a consequente invisibilidade da violência sofrida pelos mesmos, como estupros corretivos e violência doméstica. Falou também da dificuldade de entrada e permanência no mercado de trabalho, mesmo dos que conseguem retificação de nome e sexo nos documento, em virtude dos empecilhos para se conseguir uma carteira de reservista. ${ }^{35}$ No ponto alto de sua fala, disse: "A sociedade pode não nos aceitar. A sociedade pode não nos tolerar. Mas a sociedade vai ter que se acostumar com a gente. Vai ter que se acostumar com nossos corpos. Vai ter que se acostumar com homem de buceta, sim!". Arrancando aplausos, ele e outro ativista ao seu lado tiraram suas camisas e exibiram as cicatrizes de suas mamoplastias masculinizadoras: “Temos orgulho de nossas marcas!".

Nesse momento, percebe-se uma adaptação dramatúrgica do uso da expressão "mulher de peito e pau", em referência às travestis, para "homem de buceta”, em referência aos homens trans. Essa operação ressalta o caráter emblemático do corpo como ferramenta política numa estratégia usada desde o início do movimento de travestis e que coaduna com a da Marcha das Vadias, pois desnuda o corpo, mostra suas marcas e afirma: "vocês vão ter que se acostumar!” Trata-se, portanto, de um enunciado mais afirmativo que reivindicativo. Não se pede respeito, tolerância ou aceitaçáo; mas se afirma que esses corpos existem e continuarão existindo à revelia das expectativas ou desejos da sociedade englobante. Ao final, Indianara, com os seios de fora, se juntou aos dois ativistas e disse: "Para quem tem curiosidade; estes são corpos de homens trans e este é o corpo de uma mulher trans, somos mulheres de pau e homens de buceta. Aceita que dói menos!”. Muitos aplausos.

Após essa cena, vários/as outros/as ativistas subiram as escadarias e muitas fotos foram tiradas e automaticamente publicadas em diferentes redes sociais da internet. Acenderam-se velas espalhadas pelo chão em memória das pessoas trans assassinadas em 2014. Encerrado o ato, muitas pessoas continuavam por ali. As conversas eram otimistas e todos/as pareciam bastante satisfeitos/as com o resultado final. Conversei com algumas pessoas antes de me despedir, quando escuto alguém dizer: "amanhã vai ser maior”.

\section{“Amanhã vai ser maior"?}

Como afirmei no início deste artigo, não era minha intenção inicial analisar manifestaçôes de rua do ativismo trans. Parte dessa orientação decorria de uma sequência de experiências frustrantes diante de atos convocados e cancelados de última hora ou que aconteciam com um público ínfimo. Entretanto, alguma coisa mudou durante o trabalho de campo. Em junho de 2013, fui para Lisboa realizar meu estágio no exterior (doutorado sanduíche $)^{36}$ e retornei em fevereiro de 2014. Nas primeiras semanas em terras lusitanas, comecei a receber uma sequência de notícias sobre o aumento exponencial de participantes em manifestações que se alastravam pelas principais capitais do Brasil.

Posteriormente nomeadas de "Jornadas de Junho", tais manifestações começaram em São Paulo a partir da convocação do Movimento Passe Livre (MPL) para atos contra o aumento nas tarifas de ônibus na cidade. Aos poucos, as manifestações foram tomando outras capitais e cidades de médio porte. Com o aumento da repressão policial aos atos, novos manifestantes se agregaram, reivindicando a liberdade de protestar e o fim da Polícia 
Militar. Com gritos de "Amanhã vai ser maior!", aos poucos os atos ganharam proporçóes semelhantes ao "Fora Collor" e ao movimento "Diretas Jä". Entretanto, esse aumento foi permeado por um processo de individualização ou atomização da luta políti$\mathrm{ca}$, num processo em que, para cada manifestante, havia um cartaz e uma reivindicação diferente, $o$ que abriu espaço para varias disputas entre diferentes espectros da política (Frederico, 2013; Gohn, 2014; Schrer-Warren, 2014; Singer, 2013; Gajanigo e Souza, 2014; Dowbor e Szwako, 2013).

Fato foi que, quando retornei ao Brasil no início de 2014, alguma ou muita coisa havia mudado na disposição de diferentes ativistas em ocupar as ruas. Ao menos no Rio de Janeiro, onde as manifestações ganharam proporçóes gigantescas, assim como a repressáo policial, o ativismo trans havia sido afetado ao mesmo tempo em que afetou a dramaturgia política de ocupação das ruas. $\mathrm{O}$ uso da sátira e da injúria ressignificadas tornou-se um lugar-comum, assim como a produção de novas alianças com sujeitos políticos identificados como gays e lésbicas, além de novos setores feministas. Talvez nesse cenário fosse melhor dizer que tais sujeitos passaram a se identificar como "viados" ou "as gays", "sapatóes" e "vadias". Uma palavra de ordem que passou a ser repetidamente usada era: "as bi, as gay, as trava, as sapatão, tá tudo organizada pra fazer revolução!”.

Quatro vetores se interseccionam na produção (e nos conflitos) de novas dramaturgias políticas: o corpo; a rua; a internet; e a manipulação dos estigmas.

A ideia de "corpo-bandeira" não é nova para o ativismo trans. A presença de travestis com seios de fora em manifestaçóes de rua contra a violência policial vem, no mínimo, desde o final dos anos de 1980. A novidade na retomada ou reciclagem dessa tática política está na relação que ela guarda como o processo de individualização da luta política, denunciado por alguns/algumas e valorizado por outros/outras que se dedicaram à análise das "Jornadas de Junho". Assim, ao mesmo tempo que para cada manifestante um cartaz, para cada manifestante um corpo. Não se trata de uma utilização aleatória do corpo, mas de uma politização dele na evidência (e não no acobertamento) dos estigmas. Não se busca ser respeitável pela inevitabilidade (ou total descrença) na possibilidade de "respeito". O que se processa é a afirmação da presença de corpos individualizados e estigmatizados na rua.

Esse processo se vincula ao segundo vetor mencionado: a rua. Assim, não apenas o ativismo trans foi afetado pelas ocupaçóes da rua ao longo das "Jornadas de Junho", como a própria dramaturgia das manifestaçóes de rua foi afetada pela presença desses corpos. O processo de individualização da luta política, somado à tática do "corpo-bandeira", vai de encontro ao desejo (ou sonho) leninista de unidade uníssona da classe trabalhadora. Nesse sentido, a multiplicidade de corpos, bandeiras e cartazes constroem uma polifonia que tem o pluralis$\mathrm{mo}^{37}$ como condição necessária para a participação de todo e qualquer sujeito. A rua náo é mais ocupada por uma massa uniforme, mas por uma massa de corpos que por serem, cada um ao seu modo, inconformes, "desconfiam de qualquer holismo, mas anseiam por conexão", como bem coloca Donna Haraway (2000, p. 44).

Entretanto, a rua guarda uma estreita relação com as redes digitais. Se as ruas são ocupadas porque as redes foram, ou se as redes são ocupadas porque as ruas foram, parecem dilemas tautológicos. Tais dilemas permanecem na medida em que se busca, de forma inócua a meu ver, a delimitação de um palco privilegiado para a ação política. A internet esteve presente não apenas na articulação pela alteração do tema da parada e no uso do \#JeSuisTravesti e \#JeSuisTrans no ato do Dia da Visibilidade Trans de 2015, como em várias novas articulaçóes políticas. Durante as manifestações de 2013, o crescente sentimento de desconfiança com a mídia oficial causou o surgimento e fortalecimento de diferentes mídias alternativas. A mais famosa delas foi a Mídia Ninja, formada por pessoas que filmavam e transmitiam em tempo real na internet as manifestaçóes e os atos de violência policial. A Mídia Ninja também transmitiu o ato do Dia da Visibilidade Trans de 2015. A política num continuum onlinel offline não é uma aposta ativista, mas uma realidade social dada. Nessa perspectiva, a multidão de corpos inconformes e suas mazelas sociais marcham em timelines e feeds assim como em ruas e praças.

Por fim, o vetor que atravessa todos esses processos é o da manipulação dos estigmas. Creio que 
um delimitador entre o sucesso e o fracasso de manifestaçôes como as analisadas neste artigo está nas possibilidades de superação da máxima de Goffman (2008) de náo existência de solidariedade entre os estigmatizados. Tudo se passava como se as disputas pelo proscênio ativista, encenadas em atos convocados pelas organizaçóes mais tradicionais do movimento LGBT, tivessem sido substituídas por produçóes de solidariedade na identificação coletiva com o estigma e na contaminação entre regimes de visibilidade. Assim, se em outros momentos a disputa pelo foco do holofote visava construir barreiras que impedissem a contaminação de alguns/ algumas pelo estigma de outros/outras, agora é a contaminação que produz as alianças.

Parte desse processo está relacionada com uma descrença, por setores tanto feministas como LGBT, na possibilidade de angariar "respeito" através de símbolos e performances de "respeitabilidade" aceitos pela sociedade englobante. Assim, "dar-se ao respeito" não é uma tática aceita para ser respeitada/o, pois ela já é considerada ineficaz. Ao se jogar luz sobre os estigmas, a produção de solidariedade não se dá pela humanidade compartilhada de forma asséptica, inodora e incolor, mas justamente pelo polo negativo das relações sociais, pela contaminação entre diferentes regimes de visibilidade (e respeitabilidade) a partir da intrusividade dos estigmas. Ou seja, como cantou Cazuza, "somos iguais em desgraça".

\section{Notas}

1 Minha entrada em campo se deu mais precisamente em janeiro de 2009 no XVI Encontro Nacional de Travestis e Transexuais (Entlaids).

2 Utilizo aqui "travestis", "mulheres transexuais" e "homens trans" como categorias êmicas através das quais certos coletivos se identificam no campo político. De um lado, travestis e mulheres transexuais podem ser definidas, grosso modo, como pessoas assignadas ao nascer como do sexo masculino, mas que se constroem naquilo que reconhecem como feminino ou mulher; e de outro lado, homens trans são pessoas assignadas ao nascer como do sexo feminino, mas que se constroem naquilo que reconhecem como masculino ou homem. Há, no entanto, um relativo consen- so político no uso da categoria "pessoas trans" como englobante das diversas expressóes identitárias, assim como no uso de "movimento de travestis, mulheres transexuais e homens trans" como forma de explicitar os diferentes sujeitos políticos do movimento ou no uso de "movimento trans" como forma de sintetizar tais sujeitos.

3 Pesquisa "Muito Prazer, Eu Existo! Visibilidade e reconhecimento no ativismo de pessoas trans no Brasil", realizada no programa de pós-graduação em saúde coletiva do Instituto de Medicina Social da Universidade do Estado do Rio de Janeiro (IMS-Uerj) com financiamento da Coordenação de Aperfeiçoamento de Pessoal de Nível Superior (Capes).

4 João W. Nery é considerado o primeiro homem transexual do Brasil e ganhou notoriedade na mídia e na arena ativista com o lançamento de sua autobiografia, Viagem solitária: memórias de um transexual trinta anos depois, em 2011.

5 Em 2013, o ato não contou com a presença de mais do que quinze ativistas.

6 Para uma discussão mais completa sobre tais manifestações, ver Carvalho (2015).

7 Tomo a noção de "corpo-bandeira” da análise de Carla Gomes e Bila Sorj (2014) sobre a Marcha das Vadias, na qual o corpo figura simultaneamente como objeto de reivindicação e instrumento de protesto.

8 Apesar de se ter convencionado o uso da sigla LGBT durante a $1^{\text {a }}$ Conferência Nacional Gays, Lésbicas, Bissexuais, Travestis e Transexuais (GLBT), a APOGLBT mantém a sigla antiga na sua denominação.

9 Avaaz é uma organização que possibilita que qualquer pessoa em qualquer lugar do mundo crie uma petição sobre qualquer tema na internet. Após a criação, inicia-se o recolhimento de assinaturas online.

10 Segundo o jornalista Neto Lucon (2014), o tema aprovado ao final dessa reunião teria sido: "País vencedor é país sem HomoLesboTransfobia! Pela aprovação da Lei de Identidade de Gênero!”.

11 Em vários comentários e denúncias nas redes sociais a sigla "LGBT" é substituída por "GGGG" como forma de acusação da hegemonia de gays no campo político.

12 Ao usar a expressão "das trans", fica implícita uma compreensão reducionista do ativismo trans aos sujeitos cuja expressão e/ou identidade de gênero é feminina. Não é raro o uso de expressóes como "as trans" e "os trans" como abreviação de "mulheres trans" e "homens trans". Entretanto, o uso genérico no femi- 
nino ao mesmo tempo que ignora ou invisibiliza o ativismo de homens trans, também denota certo anacronismo político de quem vem de um tempo no qual tais sujeitos não estavam presentes na arena política. Por último, cabe ressaltar que a expressão também esconde ou higieniza as travestis ao englobá-las em "trans". Sobre o processo de higienização da identidade travesti na adoção de um vocabulário "trans", ver Carvalho (2011).

13 Diversas/os autoras/es descrevem o surgimento das paradas como formato privilegiado para as manifestaçóes de rua do movimento LGBT a partir da confluência em torno da ideia de "orgulho gay" de atores do mercado "GLS", do Estado e do próprio movimento. O recurso a formas lúdicas e festivas de manifestação tem suas raízes nas primeiras organizaçóes de homossexuais criadas na década de 1970 e ganha contornos de multidão e de visibilidade massiva a partir dessa intersecção mercado-movimento-Estado. Tais pesquisas também marcam as potencialidades de novas gramáticas políticas a partir do recurso lúdico e festivo que, ao mesmo tempo que amplia a participação, constrói novos formas de comunicaçáo das reivindicaçóes políticas com a sociedade englobante (Simôes e Facchini, 2009; Facchini e França, 2009; entre outras).

14 Segundo informação da APOGLBT seriam catorze trios ao todo, e o trio da Visibilidade Trans seria o décimo.

15 Ainda assim, em alguns trios de outras organizaçóes proporcionaram maior visibilidade a demanda "pela aprovação da lei de identidade de gênero", como foi o caso do Sindicato dos Professores do Ensino Oficial do Estado de São Paulo (Apeoesp).

16 Parte dessas informaçóes me foi passada por alguns interlocutores na parada e complementadas por pesquisa posterior nas redes sociais.

17 No pajubá (ou bajubá), linguagem comum entre travestis derivada de vocábulos iorubá usados em religióes de matriz africana, ekê seria um problema, truque, engano, coisa falsa. Já mona significa mulher.

18 O autor do artigo obteve autorização das pessoas fotografadas para publicação das imagens.

19 Originalmente, Associação Brasileira de Gays, Lésbicas e Travestis.

20 Para um histórico mais completo do movimento de travestis e transexuais no Brasil, ver Carvalho e Carrara (2013).

21 Duas importantes referências nesse debate são Pierre Lévy (2005) e William Gibson (2003).
22 Para uma discussão mais profunda sobre a história da internet, ver Castells (2003).

23 Em certa medida, esse tipo de questionamento tende a ignorar os movimentos de minorias sociais com pouca capacidade de visibilidade massiva a partir da quantificação de "corpos" na rua, como no caso do movimento trans.

24 O TransRevoluçáo surgiu em 2009 a partir da inserção da ativista Giselle Meirelles no Grupo Pela Vidda do Rio de Janeiro (GPV-RJ). Inicialmente pensado como um grupo de convivência de travestis e transexuais dentro do GPV-RJ, o TransRevolução acabou por se tornar o principal grupo ativista de pessoas trans na cidade do Rio de Janeiro.

25 III Seminário de Cidadania Trans, organizado pela Coordenadoria Especial da Diversidade Sexual da Prefeitura do Município do Rio de Janeiro (CEDS) e o lançamento da "Açáo Educativa de Visibilidade e Cidadania Trans", do Programa Rio sem Homofobia, do Governo do Estado do Rio de Janeiro.

26 Por processo transexualizador, compreendo todos os serviços credenciados junto ao Ministério da Saúde que disponibilizam procedimentos em diferentes níveis de complexidade com a finalidade de ofertar tecnologias de transformação corporal a pessoas trans.

27 As tags ou hashtags são uma ferramenta das redes sociais da internet para marcar fotos, textos e depoimentos sobre determinado assunto utilizando o símbolo "\#” seguido por uma mensagem sem espaços. Essa marcação facilita o processo de busca de assuntos mais comentados nas redes (os trending topics do Twitter).

28 Para um estudo mais detalhado sobre os coletivos da Marcha das Vadias em diferentes cidades do Brasil, ver Gomes e Sorj (2014).

29 Transfeminismo é uma categoria polissêmica, em disputa, que vem sendo utilizada, tanto em textos ativistas como em produçóes acadêmicas para identificar uma perspectiva feminista a partir do questionamento do sujeito político do feminismo com base nas críticas tanto do feminismo negro quanto do feminismo pós-estruturalista ao processo de essencializaçáo da mulher nos discursos feministas hegemônicos. Para uma discussão sobre os usos da categoria "transfeminismo" no contexto ativista brasileiro, ver Carvalho e Carrara (2015).

$30 \mathrm{Na}$ comunidade BeijATO no Facebook, consta: "A BeijATO é uma coletiva transfeminista anticapitalista LGBTIQ que atua contra o machismo, o racismo, a homo/lesbo/bi/transfobia e a mononormatividade" 
(www.facebook.com/pages/BeijATO/361158757321 077?fref=ts, consultado em 15/3/2015).

31 Beijaço é um tipo de manifestação comum ao ativismo LGBT no qual diversos casais homossexuais se beijam em espaço público como forma de protesto à injuria homofóbica.

32 Grupos de orientação anarquista radical que ganharam notoriedade durante as manifestaçóes de junho de 2013 e que têm entre suas principais ações políticas a depredação do que consideram grandes símbolos do capitalismo, como bancos e grandes empresas multinacionais, e em alguns casos também símbolos do Estado, como prédios governamentais e bandeiras do Brasil.

33 Os pink blocs não são uma total invençấo carioca em 2013. Segundo alguns relatos informais, ambas as terminologias (pink bloc e glitterterrotismo) já eram utilizadas por ativistas LGBT ligados a grupos anarquistas e ao ativismo de mídia independente no final dos anos de 1990 e início dos anos de 2000 na cidade de São Paulo. Entretanto, não foi possível encontrar algum tipo de relaçáo histórica ou política entre o uso paulista e o uso carioca anos depois.

34 Para maiores detalhes da história política de Indianara e sua participação na construção do movimento de travestis e transexuais, ver Carvalho (2011).

35 Atualmente, o Exército brasileiro tem dificultado a aquisição de carteira de reservista para homens trans que conseguem judicialmente a alteração do registro civil. Assim, na ausência desse documento muitos deles não conseguem um emprego formal.

36 O qual só foi possível com o apoio financeiro da Capes através do programa BDSE.

37 Esse raciocínio é inspirado na ideia de "pluralismo agonístico" de Chantal Mouffe (2005).

\section{BIBLIOGRAFIA}

ALMEIDA, Guilherme. (2005), Da invisibilidade à vulnerabilidade: percursos do "corpo lésbico" na cena brasileira face à possibilidade de infecção por DST e Aids. Tese de doutorado, Rio de Janeiro, IMS-Uerj.

ARÁN, Márcia \& MURTA, Daniela. (2009), “Do diagnóstico de transtorno de identidade de gênero às redescriçóes da experiência da transexualidade: uma reflexão sobre gênero, tecnologia e saúde”. Physis: Revista de Saude Coletiva, 19 (1): 15-63.
BAYM, Nancy. (2010), Personal connections in the digital age. Cambridge, Polity.

BELELI, Iara. (2012) "Amores online", in L. Pelúcio, L. A. F. Souza, B. R. de Magalhães e T. T. Sabatine (orgs.), Olhares plurais para o cotidiano: gênero, sexualidade e mídia, Marília (SP)/São Paulo, Oficina Universitária/Cultura Acadêmica.

CÂMARA, Cristina. (2002), Cidadania e Orientação Sexual: a trajetória do grupo Triângulo Rosa. Rio de Janeiro, Academia Avançada.

CARVALHO, Mario \& CARRARA, Sérgio. (2013), "Em direção a um futuro trans? Contribuição para a história do movimento de travestis e transexuais no Brasil". Sexualidad, Saludy Sociedad, 14: 319-351.

CARVALHO, Mario Felipe de Lima \& CARRARA, Sérgio. (2015), "Ciberativismo trans: consideraçôes sobre uma nova geraçáo militante”. Contemporânea: comunicação e cultura, 2 (13): 382-400.

CARVALHO, Mario Felipe de Lima. (2011), Que mulher é essa? Identidade, politica e saúde no movimento de travestis e transexuais. Dissertação de mestrado, Rio de Janeiro, IMS-Uerj.

CARVALHO, Mario Felipe de Lima. (2015), "Muito Prazer, Eu Existo!' Visibilidade e reconhecimento no ativismo de pessoas trans no Brasil. Tese de doutorado, Rio de Janeiro, IMS-Uerj.

CASTELLS, Manuel. (2003) A galáxia da internet: reflexóes sobre a internet, negócios e a sociedade. Rio de Janeiro, Zahar.

CASTELLS, Manuel. (2013), Redes de indignação e esperança: movimentos sociais na era da internet. Rio de Janeiro, Zahar.

DOWBOR, Monika \& SZWAKO, José. (2013), "Respeitável Público... Performance e organização dos movimentos antes dos protestos de 2013". Novos Estudos Cebrap, 97: 43-55.

FACCHINI, Regina. (2005), Sopa de Letrinhas? Movimento homossexual e produção de identidades coletivas nos anos 90. Rio de Janeiro, Garamond.

FACCHINI, Regina \& FRANÇA, Isadora Lins. (2009), "De cores e matizes: sujeitos, conexões e desafios no Movimento LGBT brasileiro". Sexualidad, Salud y Sociedad, 3: 55-81.

FREDERICO, Celso. (2013), "Da periferia ao centro: cultura e política em tempos pós-modernos". Estudos Avançados, 27 (79): 239-255. 
GAJANIGO, Paulo Rodrigues \& SOUZA, Rogério Ferreira. (2014), "Manifestaçóes sociais e novas mídias: a construção de uma cultura contra-hegemônica”. Caderno CRH, 27 (72): 577-592.

GIBSON, William. (2003), Neuromancer. São Paulo, Aleph.

GOFFMAN, Ervin. (2008), Estigma: notas sobre a manipulação da identidade deteriorada. Rio de Janeiro, LTC.

GOFFMAN, Ervin. (2009), A representação do eu na vida cotidiana. Petrópolis (RJ), Vozes.

GOHN, Maria da Glória. (2014), "A sociedade brasileira em movimento: vozes das ruas e seus ecos políticos e sociais”. Caderno $C R H, 27$ (71): 431-441.

HARAWAY, Donna. (2000), "Manifesto Ciborgue: ciência, tecnologia e feminismo socialista no final do século XX", in Silva, Tomaz Tadeu da (org.), Antropologia do ciborgue: as vertigens do pós-humano, Belo Horizonte, Autêntica.

LÉVY, Pierre. (2005), Cibercultura. Trad. Carlos Irineu da Costa. São Paulo, Editora 34.

LUCON, Neto. (2014), "Após pressão, tema da Parada LGBT de São Paulo muda e pela primeira vez dá visibilidade ao grupo trans". NLUCON, 19 fev. Disponível em www.nlucon.com/2014/2/tema-parada-lgbt-sp-lei-joao-nery-travestis-transexuais.html, consultado em 11/3/2015.

MACRAE, Edward. (1982), "Os respeitáveis militantes e as bichas loucas", in Eulálio et al., Caminhos cruzados: linguagem, antropologia, ciências naturais, São Paulo, Brasiliense.

MILLER, Daniel \& SLATER, Don. (2004), "Etnografia on e offline: cibercafés em Trinidad". Horizontes Antropológicos, 10 (21): 41-65.

MISKOLCI, Richard. (2016), "Sociologia Digital: notas sobre a pesquisa na era da conectividade”. Contemporânea, 6 (2): 275-297.

MOROZOV, Evgeny. (2011) The Net Delusion: The Dark Side of Internet Freedom. Nova York, Public Affairs.

MOUFFE, Chantal. (2005), "Por um modelo agonístico de democracia". Revista de Sociologia e Politica, 25: 12-23.

PARREIRAS, Carolina. (2015), Altporn, corpos, categorias, espaços e redes: um estudo etnográf- co sobre pornografia online. Tese de doutorado, Campinas, IFCH-Unicamp.

ROHDEN, Fabíola. (2012), "Notas para uma antropologia a partir da produção do conhecimento, os usos das ciências, intervençóes e articulações heterogêneas", in C. Fonseca, F. Rohden e P. S. Machado, Ciências na vida: antropologia de ciência em perspectiva, São Paulo, Terceiro Nome.

SCHERER-WARREN, Ilse. (2014), "Manifestaçóes de Rua no Brasil 2013: encontros e desencontros na política”. Caderno CRH, 27 (71): 417-429.

SIMÓES, Júlio A. \& FACCHINI, Regina. (2009), $\mathrm{Na}$ trilha do arco-iris: do movimento homossexual ao LGBT. São Paulo, Editora Fundação Perseu Abramo.

SINGER, André. (2013), "Brasil, junho de 2013, classes e ideologias cruzadas". Novos Estudos Cebrap, 97: 23-40. 


\section{NOTAS ETNOGRÁFICAS SOBRE DUAS MANIFESTAÇÓES DE RUA DO ATIVISMO TRANS NO BRASIL}

\section{Mario Felipe de Lima Carvalho}

Palavras-chave: Travesti; Transexual; Movimentos sociais; Manifestações de rua; Internet.

A partir da observação etnográfica da $18^{\text {a }}$ Parada do Orgulho LGBT de São Paulo (4/5/2014) e do ato pelo Dia da Visibilidade Trans do Rio de Janeiro (29/1/2015), busco tecer relaçóes entre os usos da internet, as produçóes de alianças políticas, a luta por visibilidade social e as dramaturgias políticas acionadas por ativistas trans. A opçáo por estas duas manifestaçôes se baseia nas caracterizaçôes antagônicas no que tange ao seu "sucesso político" do ponto de vista nativo (sendo a primeira considerada uma derrota frente ao sucesso da segunda), ao mesmo tempo em que acionam dramaturgias e repertórios semelhantes, a saber: 1) usos das redes sociais da internet; 2) estabelecimento de alianças com diferentes agrupamentos políticos; 3) uso do "corpo-bandeira". Por fim, busco elementos nos possíveis legados das chamadas "Jornadas de Junho" de 2013 no Brasil, tanto nas disputas representadas quanto nas diferentes avaliaçôes com relação aos (in)sucessos das manifestaçóes.

\section{ETHNOGRAPHIC NOTES ON TWO STREET DEMONSTRATIONS BY TRANS ACTIVISM IN BRAZIL}

\section{Mario Felipe de Lima Carvalho}

Keywords: Transvestite; Transsexual; Social movements; Street demonstrations; Internet.

From the ethnographic observation of the 18th São Paulo LGBT Pride Parade (5/4/2014) and of the Rio de Janeiro Transgender Day of Visibility $(1 / 29 / 2015)$, I seek to link together the uses of the internet, the productions of political alliances, the fight for social visibility and the political dramaturgies put forward by trans activists. The option of focusing on these two demonstrations is based on the antagonistic characterizations regarding its "political success" from the native point of view (with the former being considered a defeat in comparison to the latter's success), at the same time in which they put forward dramaturgies and similar repertories, to wit: 1) utilizations of social networks in the internet; 2) establishment of alliances with different political groups; 3) utilization of the "corpo-bandeira" ["flag body"]. Finally, I seek elements in the possible legacies of Brazil's so-called "Jornadas de Junho" [June Journeys] of 2013 , both in the represented disputes and the different evaluations on the demonstrations' (un)success.

\section{NOTES ETHNOGRAPHIQUES SUR LES DEUX MANIFESTATIONS DE RUE DE L'ACTIVISME TRANSSEXUEL AU BRÉSIL}

\section{Mario Felipe de Lima Carvalho}

Mots-clés: Travesti; Transsexuel; Mouvements sociaux; Manifestations de rue; Internet.

À partir de l'observation ethnographique de la 18ème Gay Pride de São Paulo $(04 / 05 / 2014)$ et l'acte en faveur de la Journée de la Visibilité Transsexuelle à Rio de Janeiro (29/01/2015), nous tentons de tisser des rapports entre les usages de l'internet, les productions d'alliances politiques, de la lutte pour la visibilité sociale et les dramaturgies politiques conduites par des activistes transsexuels. Le choix pour ces deux manifestations se base sur les caractérisations antagonistes en ce qui concerne leur « succès politique " du point de vue natif (la première étant considérée un échec face au succès de la seconde), tandis qu'en même temps elles actionnent des dramaturgies et des répertoires semblables, c'est-à-dire : 1) elles utilisent les réseaux sociaux sur internet ; 2) elles mettent en place des alliances avec différents groupes politiques ; 3) elles utilisent le " corps-drapeau ». En conclusion, nous cherchons des éléments dans les héritages possibles de ce qui a été appelé " Journées de Juin » en 2013 au Brésil, aussi bien dans les disputes représentées que par rapport aux différentes évaluations en ce qui concerne les (in) succès des manifestations. 